\title{
RESEARCH/ARAȘTIRMA
}

\section{CAN DISTRESS THERMOMETER BE USED TO MEASURE ANXIETY INDUCED SURGERY?}

\section{Gül ÇAKIR ÖZMEN ${ }^{1}$ (D) Ayla GÜRSOY ${ }^{2}$}

\begin{tabular}{ccc}
\hline Alınış Tarihi/Received & Kabul Tarihi/Accepted & Yayın Tarihi/Published \\
28.04.2021 & 28.08 .2021 & 25.09 .2021 \\
\hline Bu makaleye atıfta bulunmak için/To cite this article: & \\
Çakır Özmen G, Gürsoy A. Can distress thermometer be used to measure anxiety induced surgery? Anadolu \\
Hemşirelik ve Sağlık Bilimleri Dergisi, 2021; 24(1): 318-325. DOI: $10.17049 /$ ataunihem.929152 \\
\hline
\end{tabular}

\section{ABSTRACT}

Aim: The aim of the study is to evaluate the Distress Thermometer (DT) as a valid and reliable measurement tool that can be used to measure the patients stress because of surgery.

Method: This was a methodological study conducted with 200 patients. Data were collected using the the Hospital Anxiety and Depression Scale (HADS), the Distress Thermometer (DT) and surgery related distress causes list (DCL) for preoperative patients. The validation of the Distres Thermometer was performed in conjunction with the Hospital Anxiety and Depression Scale (HADS).

Results: Study results determined that the distress score average of the patients was 4.4 (SD 2.4), and the distress level of $47.5 \%$ of the patients was above this average. The sensitivity of HADS, which had a cut-off point of five or more, was $72.5 \%$ and specificity was $59.3 \%$. The most expressed causes of distress were the development of infection after surgery. There was a moderate relation between the thermometer score and the total DCL score and HADS total score.

Conclusion: The distress thermometer can be used as a valid tool in determining surgery-related anxiety. And also distress causes list can be used to determine distress factors. In this study, the HADS was used as a criterion for DT-DCL, and according to this scale, the sensitivity of the thermometer was high, and the specificity was moderate. The tool can be retested by using different distress scales.

Keywords: Anxiety; distress thermometer; preoperative; surgery.

$\ddot{O} Z$

Distres Termometresi Cerrahiye Bağlı Stresi Ölçmek için Kullanılabilir Mi?

Amaç: Çalışmanın amacı Distres Termometresinin (DT) hastaların ameliyat olacakları için yaşadıkları stresi ölçmek için kullanılabilecek geçerli ve güvenilir bir ölçüm aracı olma durumunu değerlendirmektir.

Yöntem: Bu metadolojik çalışma 200 cerrahi hastası ile yürütülmüştür. Veri toplama formu olarak bilgi formu, Hastane Anksiyete ve Depresyon Ölçeği (HADÖ), Distres Termometresi ve cerrahi ilişkili Stres Nedenleri Listesi kullanılmıştır. Distres Termometresinin validasyonu Hastane Anksiyete ve Depresyon Ölçeği ile yapıldı.

Bulgular: Çalışma sonuçlarında, hastaların distres puanı ortalamasının 4.4 (SD 2.4) ve hastaların \%47.5'inin distres düzeyinin bu ortalamanın üstünde olduğu belirlendi. Kesme noktası beş ve üzeri olarak saptanan HADÖ ye ait duyarlılık \%72.5, özgüllük \%59.3 olarak saptandl. Ameliyattan sonra enfeksiyon gelişme korkusu en sık ifade edilen stres nedeni olarak ifade edildi. Termometre puant ile toplam stres nedenleri listesi puani, HADS-A ve HADS toplam puanı arasında orta derecede bir ilişki bulundu.

Sonuç: Distres Termometresi ameliyatla ilgili stresi belirlemede geçerli bir araç olarak kullanılabilir. Ayrıca, strese yol açan faktörlerini belirlemek için stres nedenleri listesi kullanılabilir. Bu çalışmada, DT için HADS bir ölçüt olarak kullanıld ve bu ölçüte göre termometrenin duyarlılı̆̆l yüksek ve özgüllüğü orta düzeydedir. Termometre farklı ölçekler kullanılarak yeniden test edilebilir.

Anahtar Kelimeler: Anksiyete; distres termometresi; preoperatif; cerrahi.

\footnotetext{
${ }^{1}$ Sorumlu Yazar: Karadeniz Teknik Üniversitesi, Sağlık Bilimleri Fakültesi, Cerrahi Hastalıkları Hemşireliği, (Araş. Gör.), ORCID: 0000-0003-3805-2271 e-posta: gul_1414@hotmail.com

${ }^{2}$ Antalya Bilim Üniversitesi Sağlık Bilimleri Fakültesi, Cerrahi Hastalıkları Hemşireliği AD, (Prof. Dr.), ORCID: 0000-0003-3585-4500, e-posta: aylagursoy68@ gmail.com
} 


\section{INTRODUCTION}

The word "distress" encompasses many emotions and states of being such as sorrow, despair, weakness, fear, excitement, anxiety, panic, depression, indecision, and exhaustion (1, 2). Patients experience thoughts and emotions related to the impact of the surgery on their lives, death, being damaged, suffering, the loss of an organ, the fear of postoperative pain. Waiting for a surgical intervention, and anxiety about becoming dependent on others after a surgery (3). In addition, patients' distress in the preoperative period involves social and physiological concerns.

A very important component in a patient's healing process is the role of nurses. They determine the patient's distress during the surgery process and provide the needed care throughout the perioperative period. The nurses' expertise can help decrease patients' anxiety and negative thoughts. Thus, the complications due to distress may decrease and healing can proceed more quickly (4-6). An accelerated healing process reduces the hospitalization period and the cost of care and positively affects patients' quality of life (7-10).

A careful review of the existing literature on the subject revealed that there are various tools to determine a patient's distress. However, these tools employ many questions and require a lot of time $(11,12)$. For this reason, a tool that requires less time is needed. When compared to other scales, the Distress Thermometer is a less timeconsuming and easy-to-use tool for measuring distress. Although many studies have been conducted with cancer patients using this tool, there has thus far been no study investigating its usability in patients who will undergo or have undergone a surgery. Therefore, a measurement tool that can be applied easily and in a short time to determine surgery-related distress will prove of great benefit to both patients and medical staff.

\section{AIM}

The main aim of the present study was to evaluate validation of the distress thermometer for preoperative patients as a screening tool and to determine the cut-off score which would measure patients' distress based on surgery. And the other aim was to develop and test a questionnaire for identifying surgery-related distress causes.

\section{METHODS}

Design: This was a metadological study.

Population and Dataset: This was a methodological study conducted with 200 patients. The universe of the study was composed of patients hospitalized in the surgical clinics included in the study to undergo surgery within one year. They were selected as a result of the power analysis performed with $95 \%$ confidence interval and $80 \%$ power according to the number of patients per year bu using Openepi programme. Patients who were included in the research sample were those scheduled to undergo surgery, could read and speak in Turkish, had volunteered to participate in the study, were admitted to the clinic at least one day before the surgery, and were to undergo a surgery with general/spinal anesthesia. Excluded from the study were patients who were scheduled to undergo emergency surgery, had communication problems, were unconscious, were scheduled to undergo amputation, had vision and hearing loss, a cancer diagnosis, were scheduled to undergo surgery with local anesthesia, and were younger than 18 years and older than 65 years. Based on hospitalization orders and records, two-hundred fifty patients were interviewed until the study sample number was reached.

\section{Data Collection Tools}

Questionnaire Form: The form developed by the researchers consists of seven questions containing the sociodemographic (gender, age, marital status, educational status, working status, social security) and health status of the patients.

Hospital Anxiety and Depression Scale (HADS): The scale was used to determine the risk of anxiety in patients due to surgical intervention, to measure and evaluate the level of mood changes that may be experienced due to anxiety and measure the level of anxiety and depression in the patient. The scale was developed by Zigmond and Snaith (1983), and the validity study in our country was performed by Aydemir, Güvenir, Kuey and Kültür $(1997)(13,14)$. The two subscales within this scale are for anxiety (HADSA) and depression (HADS-D). The results of a study conducted in Turkey found the cut-off score for the anxiety subscale to be $10 / 11$ and $7 / 8$ for the depression subscale, and the areas above the cutoff score are evaluated to be at risk (13-17). The Cronbach's alpha in the current study was determined to be 0.82 for the total scale, 0.73 for the anxiety scale, and 0.66 for the depression scale, which demonstrated good internal consistency.

Distress Thermometer: The Distress Thermometer is a scale developed by Roth et al. (1998) for determining psychological distress in cancer patients (18). The thermometer is a Likert- 
type scale with scores from 0 (no stress) to 10 (excessive stress). In a short and easy-tounderstand scale, patients can easily mark their distress levels in ranges indicated on the thermometer. According to the National Comprehensive Cancer Network (19), the recommended cut-off score for the distress thermometry in cancer patients is $3 / 4(20-22)$. The Turkish validity-reliability study of the Distress Thermometer for cancer patients was performed by Özalp et al. and the recommended cut-off score for the thermometer in this study was set at four and above (23).

Distress Causes List (DCL): Along with the original Distress Thermometer used for determining the causes of distress in cancer patients, there is a symptom list (a list of items which are frequent causes of distress) to which patients are requested to give answers in the form of "yes" or "no"). Problems, which are frequently experienced and considered to be the features and causes of distress, are included in the list. It can be regarded as a checklist, which utilizes dichotomous items (yes or no) to specify needs for help or whether there is such a need. In this study, the original symptom list was not used. So, it was only inspired this list as in idea and arranged a new list which is called "distress causes list (DCL)". With purpose to create the items of this list, researchs related to preoperative anxiety/fear/distres searched by the researcher $(9$, 24-26). Then it was adressed the opinions of ten nurses working in surgical clinics, three general surgeons, one neurosurgeon, and one urologist and 20 patienst in order to test the content validity of this list.

The prepared list of causes of distress consists eight domains. Domains are related to anesthesia (four items), surgery (four items), operating room (five items), hospital (four items), physiological (13 items) and emotional (14 items) experiences after the surgery, earlier experiences (four items), and economic problems (two items). With the list of causes of distress, patients were asked to mark the causes leading to the preoperative distress, and each item selected was rated as "1" point. Thus, the total "number of stressors" can be calculated from the list of causes of distress, and each patient can score " $0-50$ " from the list. There is no any cut-off point fort his list.

\section{Ethical Aspect of the Study}

To conduct the study, the ethics committee approval was obtained from the Scientific Research Ethics Committee (24237859-465), and the institution approval was obtained from the hospital where the study was conducted. Furthermore, patients were informed about the study and their written consent was obtained. Also the author of the Turkish validity-reliability study of the distres thermometer (23) received the usage permit for the thermometer.

\section{Data Collection}

The patients who were admitted to the clinic to undergo a surgery were interviewed the day before the surgery. The face-to-face interview took place in the patient's room in a way which respected the patient's privacy.

\section{Statistical Analysis of Research}

The data obtained from the study were analyzed using the IBM SPSS 23.0 (Statistical Package for the Social Sciences) package program. In the evaluation of the breakpoint of the data, ROC analysis was performed to determine the sensitivity and specificity and the correlation between the results was examined. The findings were evaluated within the $95 \%$ confidence interval and $\mathrm{p}<0.05$ significance level. Pearson product moment correlations of the thermometer score and Distres Causes List scores with the HADS were performed. Pearson correlations (r) < 0.30 were regarded as minimum, $0.30-0.49$ as moderate, and 0.50 as strong (20). Receiver operating characteristics (ROC) and sensitivity and specificity were calculated, and thus, agreement between the HADS scales and the DTDCL was quantified. Considering previous recommendations, an AUC value in the range of 0.60-0.79 was defined as a sign of good discrimination, and an AUC value of 0.80 and above was defined as a sign of excellent discrimination in the present study (20).

\section{FINDING AND DISCUSSION}

The identifying characteristics of the patients participating in the study are shown in Table 1 . The mean value on the DT was found to be 4.4 (SD 2.4). Moderate levels of distress (4-6) were reported by $45.5 \%$ of individuals while low distress levels (0-3) were reported by $35.5 \%$ of the patients.

Distress is a negative experience experienced by most patients before surgery. Learning the distress levels and causes of patients is important for the management of distress. In the current study, we investigated DT psychometric characteristics by utilizing the information obtained from 200 patients. The mean value on the DT was found to be 4.4 (SD 2.4), the distress average for surgical patients in our country, using the distress thermometer, has been reported to be in the range of $4.7 \pm 2.8$ (27). In this study, 
however, the distress thermometer was used alone and not tested with a parallel scale.

In the current study, the AUC was 0.73 utilizing the HADS total scale, respectively, as the criteria measurement (standard error, 0.04; 95\% CI, 0.67-0.79; $\mathrm{P}<.0001$ ) (Figures 1,2 and 3). The sensitivity and specificity values for the cut-off scores determined on the DT, together with positive and negative predictive values, are summarized in Table 2.

Table 1. Demographic data of respondents $(\mathrm{n}=200)$

\begin{tabular}{|c|c|c|c|}
\hline Demographic & & $\mathbf{S}$ & $\%$ \\
\hline$A \sim$ & $18-41$ & 53 & 26.5 \\
\hline Age & $42-65$ & 147 & 73.5 \\
\hline & Female & 107 & 53.5 \\
\hline Gender & Male & 93 & \\
\hline & & & 46.5 \\
\hline Marital & Married & 169 & 84.5 \\
\hline Status & Single & 31 & 15.5 \\
\hline & Primary education & 98 & 49.0 \\
\hline $\begin{array}{l}\text { Educational } \\
\text { Level }\end{array}$ & High School & 79 & 39.5 \\
\hline & University & 23 & 11.5 \\
\hline Working & Work & 57 & 28.5 \\
\hline Status & No work & 143 & 71.5 \\
\hline Health & Yes & 197 & 98.5 \\
\hline Insurance & No & 3 & 1.5 \\
\hline & Brain $\quad$ Surgery & 61 & 30.5 \\
\hline & Clinic & 47 & 23.5 \\
\hline & General Surgery & 38 & 19.0 \\
\hline & Clinic & 33 & 16.5 \\
\hline Clinis & Urology Clinic & 21 & 10.5 \\
\hline CIIIIC & Orthopedics and & & \\
\hline & Traumatology & & \\
\hline & Clinic & & \\
\hline & $\begin{array}{l}\text { Chest and KVC } \\
\text { Clinic }\end{array}$ & & \\
\hline
\end{tabular}

The ROC curve estimates the clinically increased distress in accordance with the clinical HADS total score. Using a cut-off score of 5 (Figure 2 and 3), $72.5 \%$ of HADS "clinical HADS cases" (sensitivity) and $59.3 \%$ of HADS "nonclinical HADS cases" (specificity) were accurately determined. Clinically increased overall distress was reported by 95 individuals $(47.5 \%)$, utilizing the cut-off score of 5 on the thermometer.

According to the HADS total score, the ROC curve determining the cutting point of the distress thermometer is seen. When the cutoff point was accepted as 15 and above for the total score of HADS, it was found that the cutoff point for the distress thermometer was five and above (sensitivity: 72.5\%, specificity: 59.3\%) (p $<0.0001$ ). Study results showed that the average number of stressors was $4.6 \pm 4.6$ and $88.5 \%$ of the patients indicated at least one stressor. According to the frequency of expression, when the causes of stress of the patients are listed; The top three rankings are the anxiety of infection $(31.5 \%)$, the operating room being a cold environment (27\%) and the inability to move after surgery $(25 \%)$. To determine whether the Distres Causes List could be considered an additive scale, the Cronbach's alpha statistic found that the Distres Causes List demonstrated good consistency at 0.82 . The surgery, pre-operative physiological and emotional problems domain showed good internal consistency (Cronbach's alpha 0.680, 0.800, 0.609 , respectively). However, the domain of problems related to existing experiences was not adequate $(0.540)$ for it to be treated as an additive subscale.

According to the HADS, there was a moderate relation between the thermometer score and the Distres Causes List score $(\mathrm{r}=0.471)$, HADS-A ( $\mathrm{r}=0.426)$ and HADS total score $(\mathrm{r}=0.471)$. However, it was less correlated with the HADS-D $(\mathrm{r}=0.279)$. The DCL was less correlated with all domain scores of the problem $(0.201<\mathrm{r}>0.317)$. All sub-dimensions of the DCL were related to the HADS $(0.147<\mathrm{r}>0.304)$. This is also valid for the total problem scores $(\mathrm{r}=0.370$, $\mathrm{p}=0.000$ ).

Table 2. Sensitivity and Specificity Values of the DT-SP Thermometer Scores According to the HADS Total Score.

\begin{tabular}{lll}
\hline $\begin{array}{l}\text { Thermometer } \\
\text { Score }\end{array}$ & Sensitivity & Specificity \\
\hline$>0$ & 100 & 2.5 \\
$>1$ & 95.0 & 14.3 \\
$>2$ & 95.0 & 23.7 \\
$>3$ & 90.0 & 41.8 \\
$>4$ & 72.5 & 59.3 \\
$>5$ & 50.0 & 76.8 \\
$>6$ & 45.0 & 87.5 \\
$>7$ & 35.0 & 93.1 \\
$>8$ & 25.0 & 96.8 \\
$>9$ & 20.0 & 98.7 \\
$>10$ & 0.00 & 100 \\
\hline
\end{tabular}

To decide which score in the distress thermometer constitutes "clinical distress", it is necessary to find the cut-off score. For the present study, we selected a cut-off score with a high sensitivity, since we consider not missing patients with problems to be extremely important. Missing patients with problems can lead to false-positive 
results due to lack of optimal specificity. A cutoff score of 5 in the Distress Thermometer had optimal sensitivity relative to the HADS. Cancer patients in Turkey the DT cut-off score of 4 yielded the optimal combination of sensitivity and specificity (23). According to the results of the National Comprehensive Cancer Network $(\mathrm{NCCN})$, the best cut-off score for the Distress
Thermometer is $3 / 4(19)$.. Related sources indicate that the cut-off scores of the Distress Thermometer are between "4-5 for cancer patients' $(19,23,27-31)$. A study conducted with surgical patients in our country determined the cut-off score as three and above (27).

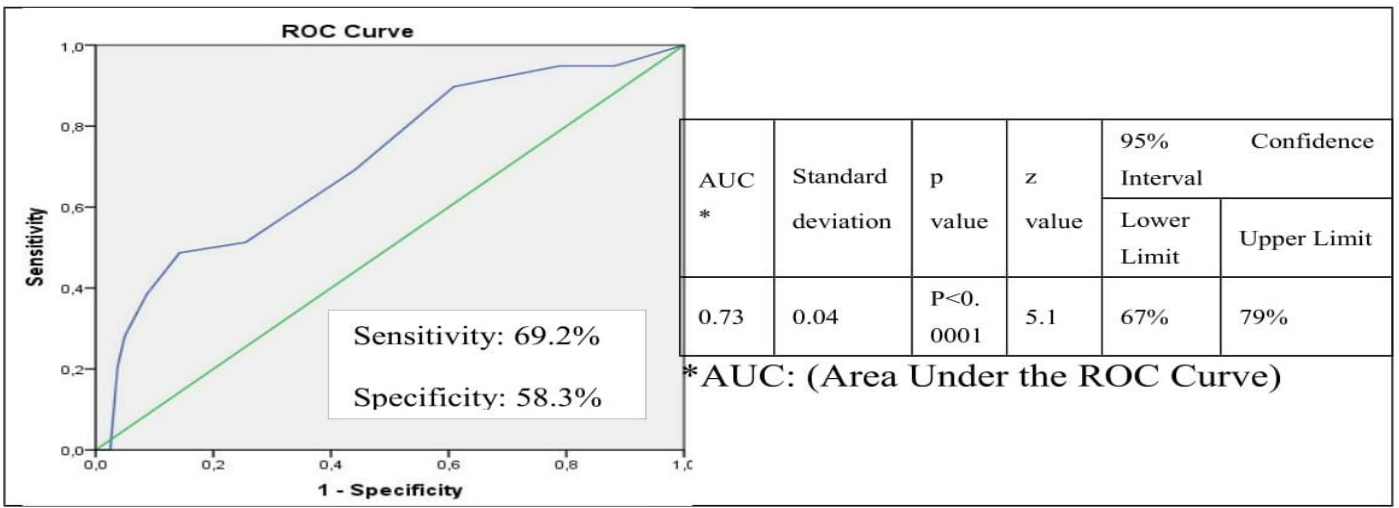

Figure 1: The ROC Curve for the Distress Thermometer According to the HADS- Anxiety

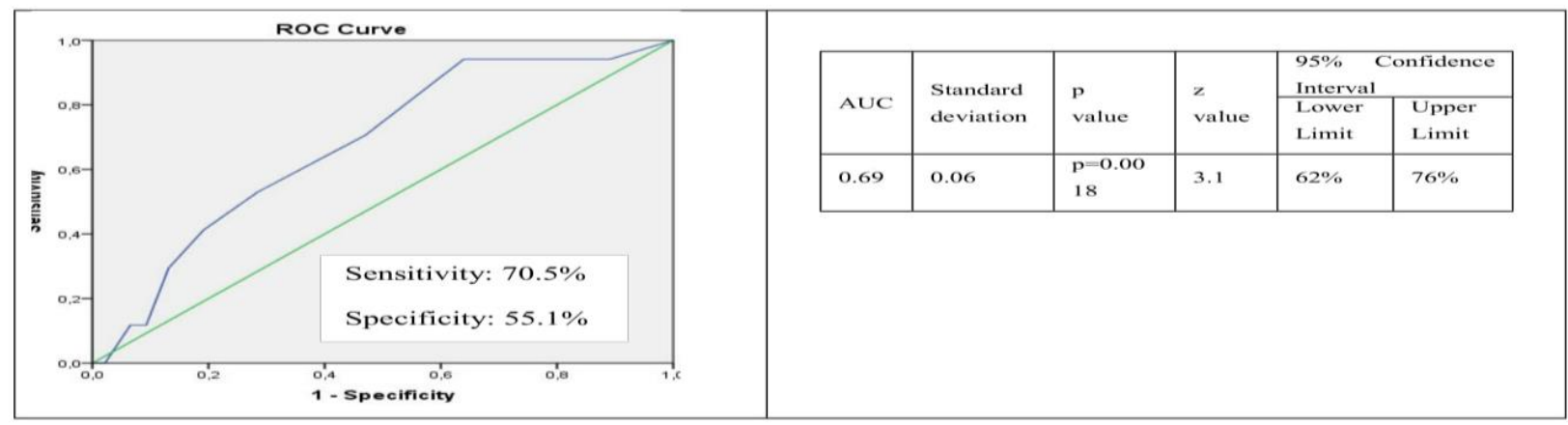

Figure 2: The ROC Curve for the Distress Thermometer According to the HADS-Depression

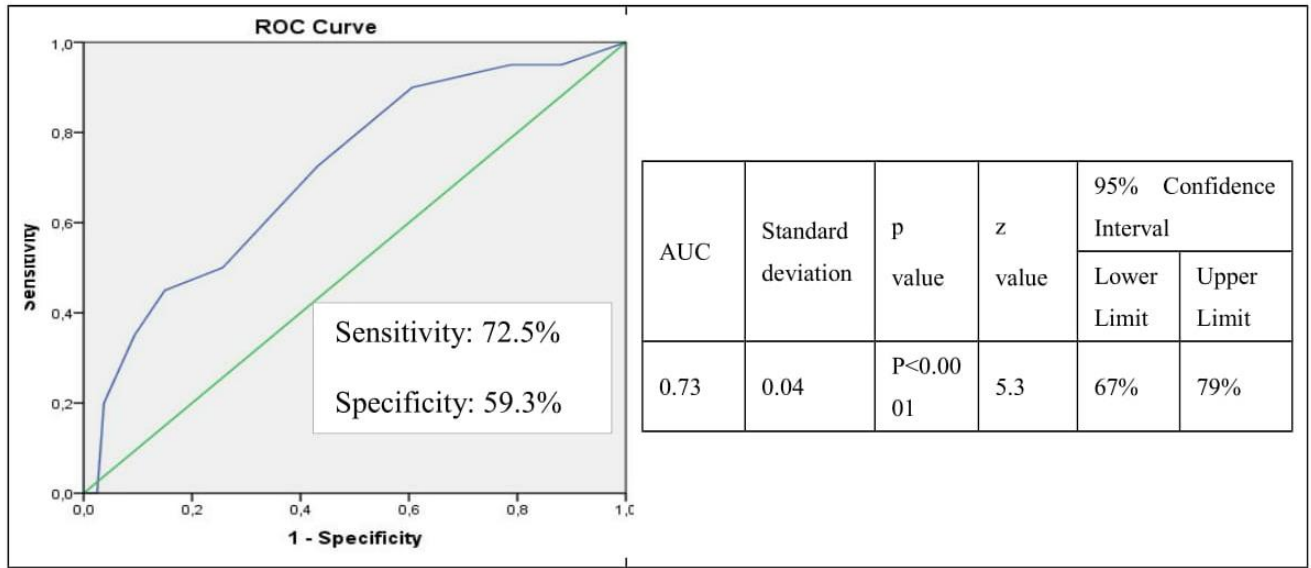

Figure 3: The ROC Curve for the Distress Thermometer According to the HADS Total Score 
The risk of designating non-distressed patients as distressed while maximizing the determination of distressed patients is increased with this cut-off score. The sensitivity according to this cut-off score was found to be $69.2 \%$ for anxiety, $70.5 \%$ for depression, and $72.5 \%$ for the total score. In the studies conducted with cancer patients, the specificity of the anxiety and depression domains ranged from $49.0 \%$ to $71.2 \%$, and the sensitivity ranged from $70.5 \%$ to $88.2 \%$. The current study's results indicate that the sensitivity scores are in line with other studies, and the specificity scores are lower $(20,23)$.

According to our study, the results obtained from the distres causes list found that patients experienced the most fear of infection development (31.5\%), and feared that the operating room was a cold environment (27\%). The internal consistency of the separate assessment of problem domains using the Distres Causes List was useful for surgery-related stressors, the post-operative physical and emotional low. Thus, this domain can be designated an additive problems domain. Only the Cronbach's alpha value of previous experiences was found to be sub-scale. In the original problem list used in many studies with cancer patients, it is stated that patients mostly experience fatigue, fatigue, fear, anxiety, pain and sleep problems (32). Since the list is not the same as the original list, we cannot compare the internal validity values.

The total score of the Distres Causes List using the DT-DCL was moderately related to anxiety and the HADS total score, however, it was less related to the total domain score and depression. This result suggests that the distress level of the patient increases as the number of stressors increases. Similarly, other earlier studies with cancer patients have reported that the scores on the DT were associated with more problems in all domains of the Distres Causes List (32-34). It is understandable that the DT-DCL results conducted with cancer patients are less related to depression $(2,23,35)$. The treatment processes of patients with cancer may be longer and more severe compared to a surgical patient. During this process, individuals may develop and experience a problem that occurs over time such as depression or physiological problems. The Distres Causes total score and all the domains were related to the HADS.

Limitations: There were a few limitations in this study, which should be noted. The first limitation is related to representativeness. These features make the results valid for a certain group. The present study was conducted as crosssectional, and the effectiveness of the DT-DCL in distress or problem resolution over time could not be assessed. It would be beneficial to carry out a longitudinal study, which could investigate the course of distress over time and assess test-retest reliability. A strong aspect of the present study was its comparatively large sample size as well as the employment of the HADS as a criterion measure, which had been used in previous studies. Nevertheless, the employment of the HADS alone as a criterion measure constitutes the limitation of the present study; future studies can be useful for the further understanding of the validity of the DT by utilizing additional criterion measures.

\section{CONCLUSION}

When the cut-off point for HADS was accepted as 15 and above, the cut-off point for the distress thermometer was found to be five and above (sensitivity: $72.5 \%$, specificity: $59.3 \%$ ). In the evaluation of anxiety related to surgery, the distress thermometer can be easily applied by both the patient and the nurse in terms of its fast and easy applicability.

Five or more $(>4)$ can be used when evaluating the anxiety of preoperative patients. The list of causes of stress used in the study can contribute to the easy identification of stress and anxiety. The results of the distress thermometer may differ in different groups and societies.

As an integral part of the surgical team, nurses spend the most time with their patients and are in a better position to know and observe each patient on an individual basis. They are thus more involved in patients' care and are better able to emotionally support each patient. Furthermore, through appropriate nursing interventions, nurses can reduce or minimize the adverse consequences caused by patients' distress from the time of admission to the clinic to the time of patients' discharge.

Acknowledge: We would like to express our gratitude to all the parents and patient associations who participated in the present study. Moreover, we would like to express our gratitude to nurses and doctors for their help in reaching the patients during the data collection, Hande Şenol for her contribution to the ROC analysis and Paula M. Knauer for her contribution to the edit.

Conflict of Interest: There is no personal or financial conflict of interest within the scope of the study.

Author Contributions: GÇÖ: Data collection and manuscript writing, analysis and 
interpretation of data, editing of manuscript. GÇÖ \& AG: Design of the study, review and final approval of manuscript.

\section{REFERENCES}

1. Klopfenstein CE, Forster E, Van Gessel E. Anesthetic assessment in an outpatient consultation clinic reduces preoperative anxiety. Canadian Journal of Anesthesia. 2000;47(6):5115.

2. VanHoose L, Black LL, Doty K, Sabata D, Twumasi-Ankrah P, Taylor S, et al. An analysis of the distress thermometer sorun list and distress in patients with cancer. Sport Care Cancer. 2015;23:1225-32.

3. Espineira $\mathrm{CH}$, Aguila MMR, Castillo MR, Valdivia AF, Sanchez IR. Relationship between anxiety level of patients and their satisfaction with differernt aspect of healthcare. Health Policy. 2009;89(1):37-45.

4. Yilmaz M, Sezer H, Gürler H, Bekar M. Predictors of preoperative anxiety in surgical inpatients. Journal of Clinical Nursing. 2012; 21(7-8): 95664.

5. Akinsulore ADESANMI, Owojuyigbe AM, Faponle AF, Fatoye FO. Assessment of preoperative and postoperative anxiety among elective major surgery patients in a tertiary hospital in Nigeria. Middle East Journal Anaesthesiol. 2015;23(2):235-40.

6. Vaughn F, Wichowski H, Bosworth G. Does preoperative anxiety level predict postoperative pain? AORN Journal. 2007;85(3):589-604.

7. Dolgun E, Dönmez CY. Determination of patient's knowledge requirements belonging to preoperative period. Journal of Nursing and Art of Maltepe University. 2010;3(3):10-6.

8. Dönmez C, Ozbayır T. Examination of the validity and reliability of the "Good Perioperative Nursing Care Scale" for the Turkish nurses and patients. Journal of Clinical Nursing. 2011;20(1\&2):16674.

9. Turhan Y, Avc1 R, Ozcengiz D. The relationship between preoperative and postoperative anxiety, and patient satisfaction in preparation for elective surgery. Journal of Anesthesia. 2012;20(1):27-33.

10. Oflaz F, Varol H. Evaluation of inpatients depression and anxiety symptoms and related. Journal of Suleyman Demirel University Medical Faculty. 2010;17(1):1-7.

11. Eskin M, Harlak H, Demirkıran F, Dereboy Ç. The adaptation of the perceived stress scale into Turkish: a reliability and validity analysis. In New Symposium Journal. 2013;51(3):132-40.

12. Asberg KK, Bowers C, Renk K, McKinney C. A structural equation modeling approach to the study of stress and psychological adjustment in emerging adults. Child Psychiatry and Human Devevlopment. 2008;39(4):481-501.
13. Zigmond AS, Snaith RP. The hospital anxietyand depression scale. Acta Psychiatria Scandinavica. 1983;6(6):361-70.

14. Aydemir O, Güvenir T, Kuey L, Kültür S. Validity and reliability of Turkish version of Hospital Anxiety and Depression Scale. Türk Psikiyatri Dergisi. 1997;8(4):280-7.

15. Nigussie S, Belachew T, Wolancho W. Predictors of preoperative anxiety among surgical patients in Jimma University Specialized Teaching Hospital SouthWestern Ethiopia. BMC Surgery. 2014;14(1): 67-71.

16. Kılınç S, Torun F. Depression rating scales used in clinical practice in Turkey. Journal of Dirim Medical. 2011;86(1):39-47.

17. Robleda G, Sillero-Sillero A, Puig T, Gich I, Baños, JE. Influence of preoperative emotional state on postoperative pain following orthopedic and trauma surgery. Revista Latino-Americana de Enfermagem. 2014;22(5):785-91.

18. Roth AJ, Kornblinth AB, Batel-Copel L, Peabody E, Scher, HI, Holland JC. Rapid screening for psychologic distress in men with prostate carcinoma: a pilot study. Cancer. 1998;82(10):1904-8.

19. NCCN. Practice Guidelines for the Management of Psychosocial Distress. National Comprehensive Cancer Network. Oncology (Williston Park). 1999;13:113-47.

20. Zwahlen D, Hagenbuch N, Carley IM, Recklitis JC, Buchi S. Screening cancer patients'families with the distress thermometer (DT): a validation study. Psycho-Oncology. 2008;17(10):959-66.

21. Baken DM, Woolley C. Validation of the Distress Thermometer, Impact Thermometer and combinations of these in screening for distress. Psycho\&Oncology. 2011;20(6):609-14.

22. Bui QUT, Ostir GV, Kuo YF, Freeman J, Goodwin JS. Relationship of depression to patient satisfaction: findings from the barriers to breast cancer study. Breast Cancer Research and Treatment. 2005;89(1):23-8.

23. Ozalp E, Cankurtaran ES, Soygür H, Ozdemir GP, Jacobsen PB. Screening for psychological distress in turkish cancer patients. Psycho-Oncology. 2007;16(4):304-11.

24. Jlala HA, French JL, Foxall GL, Hardman JG, Bedforth NM. Effect of preoperative multimedia information on perioperative anxiety in patients undergoing procedures under regional anaesthesia. British Journal of Anaesthesia. 2010;104(3):369-74.

25. Taşdemir A, Erakgün A, Deniz MN, Çertuğ A. Comparison of preoperative and postoperative anxiety levels with state-trait anxiety inventory 
test in preoperatively informed patients. Turk Journal Anaesthesiology Reanimation. 2013;41(2):44-9.

26. Ozbayır T, Demir F, Candan Y, Coşkun I, Dramalı A. The investigation of the impressions the patients related to perioperative period. Journal of Anatolia Nursing and Health Sciences. 2003;6(1):14-23.

27. Gürsoy A, Candaş B, Güner Ş, Yılmaz S. Preoperative stress: an operating room nurse intervention assessment. Journal of Perianesthesia Nursing. 2016;31(6):495-503.

28. Ryan DA, Gallagher P, Wright S, Cassidy EM. Sensitivity and specificity of the Distress Thermometer and a two-item depression screen (Patient Health Questionnaire-2) with a 'help'question for psychological distress and psychiatric morbidity in patients with advanced cancer. Psycho-Oncology. 2012;21(12):1275-84.

29. Hoffman BM, Zevon MA, D’Arrigo MC, Cecchini TB. Screening for distress in cancer patients: the NCCN rapid-screening measure. Psycho-Oncology. 2004;13(11):792-9.

30. Jacobsen PB, Donovan KA, Trask PC, Fleishman SB, Zabora J, Baker F, et al. Screening for psychologic distress in ambulatory cancer patients. Cancer. 2005;103(7):1494-502.
31. Akizuki N, Akechi T, Nakanishi T, Yoshikawa E, Okamura M, Nakano T, et al. Development of a brief screening interview for adjustment disorders and major depression in patients with cancer. Cancer. 2013;97(10):2605-13.

32. Shim EJ, Shin YW, Jeon HJ, Hahm BJ. Distress and its correlates in Korean cancer patients: pilot use of the distress thermometer and the problem list. Psycho-Oncolog. 2008;17(6):548-55.

33. Ransom S, Jacobsen PB, Booth-Jones $\mathrm{M}$. Validation of the Distress Thermometer with bone marrow transplant patients. Psycho-Oncology. 2006;15(7):604-12.

34. Tuinman MA, Gazendam-Donofrio SM, Hoekstra-Weebers JE. Screening and referral for psychosocial distress in oncologic practice. Cancer. 2008;113(4):870-8.

35. Skarstein J, Aass N, Fossa SD, Skovlund E, Dahl AA. Anxiety and depression in cancer patients: relation between the hospital anxiety and depression scale and the european organization for research and treatment of cancer core quality of life questionnaire. Journal of Psychosomatic Research. 2000;49(1):27-34. 